\title{
MENINGKATKAN KEMAMPUAN KONSEP DAN LAMBANG BILANGAN ANAK USIA DINI MELALUI MODIFIKASI PERMAINAN ULAR TANGGA
}

\author{
Lita Sri Rahayu ${ }^{1}$ \\ Husen Windayana ${ }^{2}$ \\ Nenden Ineu Herawati ${ }^{3}$
}

\begin{abstract}
ABSTRAK
Penelitian ini dilatarbelakangi oleh kurang berkembangnya kemampuan konsep bilangan dan lambang anak. Penelitian ini dilaksanakan di TK Tunas Unggulan kelas B1 dengan jumlah partisipan sebanyak 16 orang. Permasalahan ini akan diselesaikan dengan menggunakan metode modifikasi permainan ular tangga. Dalam pelaksanaannya peneliti menggunakan metode penelitian tindakan kelas model Elliot. Selama penelitian berlangsung peneliti mengumpulkan data menggunakan penilaian performa, observasi anak, observasi guru, wawancara dan dokumentasi. Berdasarkan data yang diperoleh diketahui bahwa hasil penilaian performa anak dengan menggunakan modifikasi permainan ular tangga pada setiap siklus adalah sebagai berikut. Pada indikator kesatu yakni memasangkan lambang bilangan dengan benda-benda 1-10 siklus I sebesar 35,89\%, siklus II 67,35\% dan pada siklus III sebesar 75,15\%. Indikator kedua yakni membilangan urutan bendabenda 1-20 siklus I sebesar 41,02\%, siklus II 58, $16 \%$ dan siklus III sebesar $75,15 \%$. Indikator ketiga yakni meniru bentuk lambang bilangan 1-10 siklus I sebesar 25,63, siklus II sebesar 45,82 dan siklus III sebesar 64,07\%. Adapun rekomendasi yang peneliti ajukan yaitu penerapan permainan ular tangga modifikasi akan meningkatkan kemampuan konsep bilangan dan lambang dengan lebih optimal, jika pada setiap permainan ular tangga melibatkan anak sebagai bidaknya sendiri serta kegiatan yang dirancang menarik dan sesuai kebutuhan anak.

Kata Kunci: Konse, Lambang Bilangan, Permainan ular tangga, Modifikasi.

Anak usia dini adalah individu yang memiliki banyak potensi yang harus dikembangkan melalui stimulus dan bimbingan. Mereka adalah individu unik yang sedang mengalami pertumbuhan dan perkembangan yang pesat sehingga sering disebut dengan masa Golden Age atau masa keemasan. Pada triwulan pertama kehamilan, organ yang paling cepat berkembang ialah otak. Otak janin yang berada di kandungan seorang ibu mengalami perkembangan yang sangat cepat. Setiap menitnya, sel saraf yang berada di otak janin bertambah hingga 25.000 sel. Hal ini terus berlanjut sampai menjelang kelahirannya dimana sel otak bayi telah mencapai hingga 100 milyar sel saraf. Bisa dibayangkan apabila tidak distimulasi dengan baik maka sel-sel tersebut tidak akan berfungsi bahkan rusak. Namun apabila sel saraf anak yang berjumlah milyaran tersebut dikembangkan dan distimulasi dengan baik maka betapa cerdasnya seorang anak.
\end{abstract}

\footnotetext{
${ }^{1}$ litasrirahayu 17@yahoo.com

${ }^{2}$ Dosen Kampus UPI Cibiru

${ }^{3}$ Dosen UPI Kampus Cibiru
} 


\section{A. PENDAHULUAN}

Masa kanak-kanak adalah masa yang paling kritis dalam pembentukan sistem saraf otak manusia setelah pembentukan janin di dalam kandungan. Oleh sebab itu perlunya stimulus yang dapat mengembangkan otak anak pada masa ini yakni melalui pendidikan anak usia dini. Pendidikan anak usia dini adalah suatu upaya pemberian stimulus, bimbingan, dan pengasuhan pada seluruh aspek perkembangan anak. Sebagaimana dalam Undang-undang Nomor 20 Tahun 2003 tentang Sistem Pendidikan Nasional pada Pasal 1 butir 14 (2013) bahwa:

Pendidikan anak usia dini didefinisikan sebagai suatu upaya pembinaan yang ditujukan kepada anak sejak lahir sampai dengan usia enam tahun yang dilakukan melalui pemberian rangsangan pendidikan untuk membantu pertumbuhan dan perkembangan jasmani dan rohani agar anak memiliki kesiapan dalam memasuki pendidikan lebih lanjut (hlm. 4).

Salah satu dari pendidikan anak usia dini ialah Taman Kanak-kanak (TK). Taman Kanak-Kanak dapat dipilih sebagai lembaga yang mampu mengembangkan potensi dan aspek anak usia 4-6 tahun. Sebagaimana yang tertulis dalam pasal 28 ayat 2 UU RI No. 20 Tahun 2003 (dalam Syaripudin, 2003, hlm. 169) menyatakan

bahwa "Taman Kanak-kanak menyelenggarakan pendidikan untuk mengembangkan kepribadian dan potensi diri sesuai dengan tahap perkembangan peserta didik". Dengan adanya lembaga TK maka, potensi dan seluruh aspek perkembangan anak dapat dioptimalkan dengan cara membimbing dan menstimulusnya. Terdapat banyak aspek yang harus dikembangkan pada anak usia dini di antaranya, aspek fisik motorik, bahasa, kognitif, sosial emosional, dan moral agama. Salah satu aspek perkembangan yang perlu dikembangkan pada anak adalah aspek perkembangan kognitif.

Depdiknas (2007, hlm. 3) mengungkapkan bahwa "Pengembangan kognitif adalah suatu proses berpikir berupa kemampuan untuk menghubungkan, menilai dan mempertimbangkan sesuatu. Dapat juga dimaknai sebagai kemampuan untuk memecahkan masalah atau untuk mencipta karya yang dihargai dalam suatu kebudayaan". Jadi, bukan hanya sebagai penentu kecerdasan saja, jika seorang anak yang memiliki perkembangan kognitif yang baik maka ia akan memiliki kemampuan memecahkan masalah dan memiliki pemikiran yang kritis, 
berimajinasi, bereksplorasi, dan lain-lain. Aspek kognitif pun dibagi kedalam 2 bagian yakni, kemampuan sains dasar, dan kemampuan matematika dasar. Cakupan pengembangan kognitif setiap kelompok usia mempunyai karakteristik yang berbeda-beda, sebagaimana tercantum dalam kurikulum TK yang di antaranya mengembangkan kemampuan matematika dasar.

Dalam Depdiknas (2007, hal. 14) kemampuan matematika dasar yang perlu dikembangkan pada anak TK usia 5-6 tahun (kelompok B) antara lain membilang/ menyebut urutan bilangan dari 1 sampai 20, membilang (mengenal konsep bilangan dengan benda-benda) sampai 10, membuat urutan bilangan 1-10 dengan benda-benda, menghubungkan/memasangkan lambang bilangan dengan bendabenda sampai 10 (anak tidak disuruh menulis).

Anak usia 5-6 tahun diharapkan dapat mencapai standar pencapaian yang telah ditetapkan. Salah satu kemampuan matematika dasar yang diharapkan dapat dicapai anak adalah kemampuan konsep bilangan dan lambangnya.

Menurut Piaget (dalam Sriningsih, 2009, hlm. 30) perkembangan matematika anak usia 5-6 tahun sudah berada dalam tahap symbolic karena pada tahap ini anak memasuki tahap pra operasional dimana anak sudah mampu menggunakan simbol- simbol dalam pikirannya untuk mempresentasikan benda atau kejadian. Sehingga pada usia itu anak dipandang sudah matang untuk memahami konsep bilangan melalui gambar dan mengenal lambang bilangan sebagai symbol dari suatu konsep. Menguasai konsep dan lambang bilangan merupakan salah satu cara agar aspek kognitif anak dapat berkembang.

Kenyataan di lapangan, kemampuan anak dalam memahami konsep bilangan dan lambangnya masih rendah meskipun ada beberapa anak yang sudah bisa. Hal ini terjadi pada TK Tunas Unggulan kelompok B1, dimana saat pembelajaran anak-anak sudah bisa membilang angka 1-20, akan tetapi saat angka tersebut di acak urutannya, anak- anak masih kebingungan dalam menyebutkan angka tersebut. Selanjutnya saat kegiatan menghubungkan lambang dengan bilangannya anak pun masih kebingungan. Dilihat dari permasalahan tersebut, sudah dapat dikatakan bahwa kemampuan mengenal lambang bilangan anak-anak kelompok B1 di TK Tunas Unggulan masih rendah.

Jika dianalisis lebih mendalam, terdapat beberapa faktor yang menyebabkan anak belum mampu memahami konsep bilangan dan lambangnya. Perkembangan kognitif anak yang masih dalam tahap perkembangan dapat menjadi faktor yang utama dalam pemahamannya mengenai konsep bilangan dan lambangnya. Selain itu, metode pembelajaran yang dipakai oleh guru masih dengan metode konvensional. Hal ini terlihat saat pembelajaran, guru yang lebih dominan berbicara sedangkan anak hanya duduk rapih di kursi dan meja tanpa adanya pengalaman yang menarik bagi anak. Pembelajaran yang demikian akan menimbulkan rasa bosan pada anak, sehingga anak tidak mau belajar dan tidak semangat untuk belajar. Seorang guru perlu mengemas pembelajaran dengan kreatif dan menarik bagi anak untuk memunculkan rangsangan yang baik, sehingga anak merasa tertarik dan bersemangat untuk belajar.

Pembelajaran yang mengesankan dan menarik bagi anak tentu yang sesuai dengan dunia anak. Dunia belajar anak bukanlah dengan duduk di kelas dan mendengarkan guru berbicara. Akan tetapi pembelajaran melalui kegiatan yang 
sangat menyenangkan dan membuat anak bergairah. Kegiatan tersebut adalah kegiatan bermain. Kegiatan bermain sangatlah berpengaruh terhadap perkembangan dan pertumbuhan anak baik secara fisik maupun secara psikologis serta berpengaruh pula terhadap perkembangan intelegensinya.

Bermain merupakan dunia anak yang tidak bisa dipisahkan dari kehidupan mereka. Melalui bermain dapat membuat anak menjadi tenang. Anak-anak akan merasa senang dan tertarik saat mengikuti pembelajaran karena dilakukan melalui kegiatan bermain. Sehingga secara tidak langsung kemampuan anak dalam mengenal lambang bilangan akan semakin meningkat. Sehingga permainan yang bisa digunakan dalam meningkatkan kemampuan menguasai konsep bilangan dan lambangnya adalah permainan yang menyuguhkan jumlah gambar sebagai bilangan benda, dan symbol/ lambang dari suatu bilangan.

Banyak ragam permainan yang menarik dan asyik yang dapat meningkatkan pemahaman anak terhadap lambang bilangan, salah satunya adalah permainan ular tangga. Permainan ini belum pernah dilakukan oleh guru sebelumnya sebagai metode dalam meningkatkan kemampuan memahami konsep bilangan dan lambangnya pada anak. Sehingga peneliti akan menggunakan permainan ini sebagai cara untuk menstimulasi anak agar dapat mengenal lambang bilangan. Sebagaimana yang diungkapkan oleh Cahyo (dalam Laelasari, 2012, hlm. 24) mengemukakan bahwa "Dengan bermain ular tangga, otak kiri anak akan diasah untuk menghafal nomor, belajar berhitung (menjumlah), mengenal angka, mengurutkan langkah, dan lain- lain". Oleh karena itu, dengan permainan ular tangga dapat meningkatkan kemampuan anak dalam mengenal lambang bilangan.

Namun, permainan sebaiknya menarik dan berbeda agar anak memiliki ketertarikan saat memainkannya karena anak usia dini selalu cepat bosan. Dalam hal ini peneliti akan memodifikasi permainan ular tangga menjadi lebih berbeda daripada permainan ular tangga pada umunya. Peneliti memodifikasi ukuran, dan unsur-unsur dalam permainan ular tangga. Sebagaimana Menurut Wardani (2009, hlm. 123) bahwa media yang paling cocok untuk keperluan pembelajaran adalah bermain atau permainan yang dimodifikasi. Hal ini bertujuan agar anak merasa penasaran dan tidak merasa bosan dengan permainan yang diberikan, ia akan merasa semangat dan senang sehingga diharapkan anak mau belajar dengan cara yang menyenangkan tanpa ada paksaan dari orang lain. Sehingga diharapkan dengan modifikasi permainan ular tangga ini dapat meningkatkan kemampuan anak dalam mengenal lambang bilangan.

\section{B. METODE}

Metode penelitian yang akan peneliti gunakan dalam penelitian ini adalah metode Penelitian Tindakan Kelas (PTK). Penelitian Tindakan Kelas adalah penelitian yang dilakukan untuk memecahkan suatu permasalahan dalam pembelajaran di kelas yang kemudian permasalahan tersebut dikaji dan diperbaiki melalui tindakan saat proses pembelajaran berlangsung secara berulang atau bersiklus. PTK merupakan jenis penelitian kombinasi antara penelitian kuantitatif dan kualitatif. Penelitian kuantitatif menitikberatkan pada aktivitas atau proses dalam penelitian yakni berupa deskriptif. Sedangkan penelitian kualitatif lebih pada perhitungan data berupa angka (statistika) yakni hasil dari penelitian. Dalam 
penelitian tindakan kelas terdapat kedua hal tersebut yakni proses dan hasil sehingga dapat disimpulkan bahwa penelitian tindakan kelas merupakan penelitian bersifat kuantitatif dan kualitatif yang dilakukan untuk memecahkan masalah, mengkaji masalah tersebut, dan memperbaikinya melalui tindakan saat proses pembelajaran berlangsung secara berulang atau bersiklus.

Dalam penelitian ini kemampuan anak yang akan ditingkatkan ialah kemampuan matematika dasar anak dalam mengenal lambang bilangan. Penulis memilih menggunakan jenis penelitian tindakan kelas dikarenakan sebelumnya terdapat masalah yang terjadi di kelas yang selanjutnya akan ditingkatkan melalui metode bermain yakni modifikasi permainan ular tangga yang tujuannya untuk memperbaiki masalah yang ada. Dalam hal ini penguasaan konsep bilangan dan lambang bilangan tidak bisa dilakukan dengan hanya 1 kali pertemuan, akan tetapi harus dilakukan melalui kegiatan pengulangan dan pembiasaan. Dalam mengenal lambang bilangan tidak bisa dikuasai apabila hanya dihapalkan saja sehingga harus dilakukan melalui latihan. Karena untuk memperoleh kemampuan dalam memahami matematika perlu adanya latihan (drill) berkali-kali dan secara terus menerus. Hal ini sejalan dengan karakteristik PTK yakni adanya tindakan yang berulang atau sering disebut dengan siklus.

Permasalahan yang terjadi di TK Tunas Unggulan adalah masih rendahnya pemahaman anak terhadap konsep bilangan dan lambangnya. Oleh karena itu perlu adanya upaya dalam peningkatan kemampuan anak dalam konsep bilangan dan lambangnya Dilihat dari permasalahan yang muncul, PTK memiliki peran dalam memecahkan masalah dalam proses pembelajaran serta meningkatkan kemampuan anak. Hal ini bertemali dengan tujuan PTK dalam meningkatkan dan memperbaiki kualitas proses dan hasil pembelajaran diantaranya meningkatkan atau memperbaiki kinerja siswa di sekolah, meningkatkan dan memperbaiki mutu dalam proses pembelajaran di kelas, meningkatkan dan memperbaiki masalah- masalah pendidikan anak di sekolah (Abidin, 2011, hlm. 221).

Penelitian ini dilakukan di TK Tunas Unggulan Komplek Adipura pada anak kelompok B1 dengan jumlah 16 orang anak. Instrumen penelitian berguna untuk mengumpulkan data dalam PTK. Instrumen yang digunakan meliputi lembar penilaian performance, lembar observasi guru dan siswa, catatan lapangan, lembar wawancara, dan dokumentasi/kamera foto.

Pengumpulan data dalam PTK ini, menggunakan observasi, wawancara, catatan lapangan, dan dokumentasi Pengumpulan data ini bertujuan untuk mengetahui bagaimana proses pembelajaran yang telah dilaksanakan. Teknik analisis data yang digunakan dalam penelitian ini yaitu, data kuantitatif dan data kualitatif. Data kuantitatif diperoleh dari hasil penilaian performance anak ketika mendapat bintang yang diolah menjadi angka-angka atau nilai rata-rata persentase anak, serta dapat disajikan menjadi bentuk grafik. Sedangkan data kualitatif diolah secara deskriptif berdasarkan dari pengumpulan data yang diperoleh dari wawancara, catatan lapangan, dan observasi. Analisis data ini dilakukan ketika akhir pelaksanaan penelitian, hal ini dapat memudahkan untuk menganalisis data yang telah terkumpul. 


\section{PEMBAHASAN}

Pada siklus I terdiri dari 3 tindakan yaitu pada tindakan 1 membahas tema ciri- ciri pedesaan, tindakan 2 membahas tema pekerjaan di desa, dan tindakan 3 membahas tema mata pencaharian di kota. Kegiatan pembelajaran dilakukan dengan cara bermain yakni bermain ular tangga modifikasi. Pembelajaran tersebut diperlukan peran guru yang aktif dan kreatif agar kemampuan konsep bilangan dan lambang pada anak TK Tunas Unggulan dapat meningkat.

Pada siklus I guru memulai dengan materi konsep bilangan dan lambang yang bertahap yakni anak memasangkan lambang bilangan dengan benda-benda 15, anak membilang benda-benda 1-9 dan anak meniru bentuk lambang bilangan 15. Tahapan materi ini dibuat karena saat anak memahami sesuatu hal tidak bisa sekaligus sehingga harus ada tahapan-tahapannya.

Adapun temuan-temuan pada Siklus I tindakan 1 ini adalah kemampuan dalam konsep bilangan dan lambangnya belum terlihat meningkat hal ini dikarenakan anak belum memahami terhadap aturan permainan ular tangga, anak masih kebingungan saat memulai permainan dan masih banyak yang harus dibantu oleh guru. Selain itu, disaat guru membacakan cerita, anak-anak terlihat bosan dan media yang digunakan tidak mendapat perhatian lebih dari anak. Sedangkan pembelajaran pada anak harus dimunculkan media sebagai pendukung. Hal ini diperkuat oleh Sudjana dan Rivai (dalam Sundayana, hlm. 8) bahwa salah satu fungsi pokok media pembelajaran dalam proses pembelajaran adalah "Media pengajaran bukan sebagai alat hiburan, akan tetapi alat ini dijadikan untuk melengkapi proses belajar mengajar supaya lebih menarik perhatian peserta didik".

Pada saat pelaksanaan permainan ular tangga beragam ekspresi anak muncul, ada yang senang, ada juga yang masih kebingungan saat bermain. Pada saat kegiatan bermain guru perlu memberikan motivasi kepada anak agar ia lebih bersemangat saat bermain. Sejalan dengan pendapat Sagala (dalam Laelasari, 2012, hal. 146) "Konsep pembelajaran motivasi berarti seni mendorong peserta didik untuk terdorong melakukan kegiatan belajar sehingga tujuan pembelajaran tercapai". Kemudian pada saat anak telah memenangkan permainan, anak kurang begitu senang dengan reward yang diberikan oleh guru karena reward tersebut berupa reward verbal saja karena reward merupakan salah satu bentuk dari penguatan.

Penguatan yang diberikan oleh guru bukan hanya berbentuk verbal tetapi dalam bentuk non verbal. Menurut Sanjaya (2013, hlm. 38) "Penguatan nonverbal juga dilakukan dengan memberikan tanda-tanda tertentu, misalnya penguatan dengan melakukan sentuhan, berjabat tangan atau menepuk-nepuk pundak siswa". Dalam hal ini guru memberikan reward berupa bintang.

Pada tindakan 2 anak-anak sudah terlihat antusias saat melakukan permainan ular tangga modifikasi. Namun pada saat menunggu giliran bermain terlihat tidak kondusif karena anak saling berebut posisi agar mendapatkan posisi yang paling depan. Hal ini berkaitan dengan pendapat Solehuddin (dalam Laelasari, 2012, hal. 148) bahwa pada anak usia TK masih sering terjadi konflik atau berebut sesuatu karena sifat egosentrisnya yang masih melekat".

Ketika anak memasangkan lambang dengan benda-benda, anak kesulitan untuk mengambil benda karena ukurannya yang terlalu kecil. Sedangkan, sebuah 
media harus dimunculkan dengan ukuran yang bisa di sentuh sehingga memudahkan anak. Hal ini sama terjadi pada tindakan 3 dimana ukuran dadu yang kurang besar membuat anak kesulitan saat membilang titik pada dadu tersebut.

Temuan lainnya pada tindakan 3 ialah pada saat anak meniru bentuk lambang bilangan tidak lagi dilakukan di udara melainkan guru merubahnya dengan meniru lambang bilangan di pasir. Hal ini dilakukan agar anak dan guru mengetahui secara nyata dan jelas lambang bilangan yang dibuat oleh anak, sehingga bisa diperbaiki.

Kemampuan konsep bilangan dan lambang anak pada tindakan 3 ini hampir seluruh anak sudah terlihat adanya peningkatan dalam menghubungkan lambang dengan benda-benda 1-5, membilang benda-benda 1-9 dan meniru bentuk lambang bilangan 1-5. Namun pada saat membilang titik pada dadu, anak terlihat kesulitan dan lebih lama membilang titik tersebut. Hal ini dikarenakan ukuran dadu yang kurang besar sehingga menyulitkan anak saat membilang titiknya.

Pada siklus II materi yang dikenalkan pada anak lebih ditingkatkan lagi pada setiap indikatornya yakni indikator 1, anak mampu menghubungkan lambang bilangan dengan benda-benda 1-7. Pada indikator 2, anak mampu membilang urutan benda- benda 1-15. Pada indikator 3, anak mampu membentuk lambang bilangan 1-7. Pembahasan pada tindakan 1 yakni membahas mengenai mata pencaharian di kota, tindakan 2 membahas mengenai pesisir pantai dan tindakan 3 masih membahas mengenai pesisir pantai.

Kegiatan yang dilakukan pada tindakan 1 adalah praktek sholat, bercerita mengenai seorang koki dan bermain ular tangga. Pada tindakan 2 kegiatan yang dilakukan anak adalah olah raga/ senam prahyangan, Menggambar pesisir pantai, bernyanyi "ikanku" dan bermain ular tangga modifikasi. Pada tindakan 3 kegiatan yang dilakukan adalah Sholat dan dzikir, menebalkan dan mewarnai huruf hijaiyah, Bernyanyi tentang perahu dan bermain ular tangga.

Aktivitas pada saat proses pembelajaran di Siklus II tindakan 1 mengalami peningkatan dan penurunan hal ini disebabkan oleh kondisi saat menunggu giliran bermain ular tangga tidak kondusif karena ada beberapa anak yang bertengkar disebabkan saling berebut posisi. Sebagaimana menurut Solehuddin (dalam Laelasari, 2012, hal. 148) bahwa pada anak usia TK masih sering terjadi konflik atau berebut sesuatu karena sifat egosentrisnya yang masih melekat". Sehingga saat anak bermain ular tangga tidak akan lagi dilakukan dengan cara mengantri tetapi dilakukan oleh empat orang anak dan anak yang lainnya melakukan kegiatan lain.

Pada saat anak akan melangkahkan bidaknya, ia kebingungan dan harus mencari terlebih dahulu nama yang ada di belakang bidaknya tersebut. Hal tersebut disebabkan media bidak yang disediakan oleh guru antara satu anak dan satu anak lainnya serupa sehingga anak sering terlihat kebingungan yang menyebabkan berlangsungnya kegiatan bermain ular tangga tidak kondusif. Oleh sebab itu dengan adanya temuan ini guru perlu melakukan perbaikan dengan merubah bidak dengan bentuk dan warna yang beraneka ragam sehingga pada saat bermain bidak yang dimainkan anak tidak akan tertukar dengan yang lainnya.

Pada saat guru bercerita, anak sudah terlihat bosan dengan cerita yang dibawakan oleh guru. Hal ini disebabkan oleh sifat anak yang tidak bisa diam lebih lama dan mendengarkan sesuatu hal. Anak lebih senang bergerak dan 
mengeksplorasi benda-benda yang ada disekitarnya. Hal tersebut berkaitan dengan pendapat Berg (dalam Solehuddin, 200, hlm. 67) bahwa "Sepuluh menit waktu yang wajar bagi anak usia sekitar 5 tahun ini untuk dapat duduk dan memperhatikan sesuatu dengan nyaman". Sehingga guru akan memberikan stimulasi kepada anak dengan bernyanyi disaat sebelum dan dalam melakukan bermain ular tangga. Sebagaimana pendapat Komariah (dalam jurnal Pendidikan Anak Usia Dini, 2013. Halm. 89) bahwa " Memperkenalkan konsep bilangan pada anak usia dini dapat dilakukan dengan cara bernyanyi

Pada tindakan 1, anak mengalami kesulitan saat bermain uar tangga karena ruangan yang kurang luas sehingga ruang gerak anak tidak maksimal. Hiasan yang ada di dinding menjadi kendala saat guru harus menempelkan papan ular tangga. Dibutuhkan area khusus untuk bermain ular tangga agar anak lebih nyaman saat bermain. Hal ini sejalan dengan pendapat Mariyana, dkk (2010, hlm. 52) bahwa "Penataan ruang kelas yang baik, rapih, indah dan terstruktur, akan lebih memudahkan anak dan guru dalam melakukan pembelajaran.

Pada tindakan 2 kemampuan anak terhadap konsep bilangan dan lambang mengalami peningkatan dari tindakan sebelumnya. Namun guru menemukan temuan pada saat proses pembelajaran yang membuat anak yang lain belum mengalami peningkatan. Pada saat anak yang belum mendapatkan giliran bermain ular tangga, ia ingin melihat temannya bermain ular tangga. Hal ini menjadi penyebab anak tidak menyelesaikan LKA yang diberikan oleh guru. Hal tersebut berkaitan dengan pendapat Berg (dalam Solehuddin, 200, hlm. 67) bahwa "Sepuluh menit waktu yang wajar bagi anak usia sekitar 5 tahun ini untuk dapat duduk dan memperhatikan sesuatu dengan nyaman". Oleh sebab itu guru akan melakukan perbaikan yakni memberikan reward kepada anak yang sudah menyelesaikan kegiatan LKA

Pada tindakan 3 pembelajaran permainan ular tangga modifikasi berlangsung dengan tertib dan anak terlihat sangat antusias saat melakukannya. Kemampuan konsep blangan dan lambang pada tindakan 3 ini mengalami peningkatan yang baik. Namun pada tindakan 1 peningkatan kemampuan konsep bilangan dan lambang setiap indikator belum meningkat dengan baik. Akan tetapi pada tindakan 2 kemampuan tersebut meningkat perlahan.

Pada siklus III materi yang dikenalkan pada anak lebih ditingkatkan lagi pada setiap indikatornya yakni indikator 1, anak mampu menghubungkan lambang bilangan dengan benda-benda 1-10. Pada indikator 2, anak mampu membilang urutan benda- benda 1-20. Pada indikator 3, anak mampu membentuk lambang bilangan 1-10. Pembahasan pada tindakan 1 yakni membahas mengenai mata pencaharian di kota, kegiatan yang dilakaukan ialah menebalkan dan mewarnai huruf h-i-n-d-u, b-u-d-h-a, i-s-l-a-m, k-r-i-s-t-e-n, dan bermain ular tangga.

Tindakan 2 dan 3 membahas mengenai pesisir pantai, kegiatan pada tindakan kedua yaitu mozaik gambar ubi dan singkong, bernyanyi tentang ubi dan singkong serta bermain ular tangga modifikasi. Kegiatan pada tindakan ketiga yaitu praktek sholat, mewarnai huruf hijaiyah, bernyanyi tentang bendera dan bermain ular tangga.

Aktivitas pembelajaran pada siklus III ini mengalami peningkatan yang baik. Pada tindakan 1, 2 dan 3 anak-anak sudah terlihat antusias saat bermain ular 
tangga. Namun pada saat guru memberikan stimulasi mengenai cara meniru bentuk lambang bilangan harus ditambahkan dengan cara bernyanyi. Sebagaimana menurut Mulyati (2010, hlm. 52-53) bahwa " Dengan menyanyikan lagu dan melihat peragaan jari yang menerangkan bilangan yang sedang dibicarakan merupakan cara efektif, karena anak belajar melalui mengamati dan meniru dalam situasi yang menyenangkan sehingga mereka lebih cepat menangkapnya".

Pada tindakan kedua, ketika anak melangkah dan membilang benda-benda, anak merasa bosan karena dilakukan hanya dengan duduk saja. Sementara anak usia dini harus lebih banyak bergerak dan mengeksplorasi apa saja yang ada disekitarnya. Pada tindakan ketiga, temuan yang muncul ialah anak menginginkan keseluruhan permainan ular tangga lebih banyak melibatkan seluruh inderanya. Misalnya saat bermain, anak sendiri yang menjadi bidak, ketika meniru bentuk lambang bilangan dapat dilakukan dengan cara meniru menggunakan seluruh badan anak. Hal ini terbukti ketika anak membilang dengan cara melangkah sambil melompat, ia lebih merasa senang dan antusias, fisik motorik anak pun dirasa akan lebih meningkat. Namun hal tersebut menjadi kendala jika dilakukan di tempat dan ruangan yang sempit dan kurang nyaman.

Adapun kemampuan konsep bilangan dan lambang anak pada siklus III ini meningkat dengan signifikan karena pada saat anak membilang benda-benda tidak lagi menggunakan gambar melainkan benda-benda konkrit sebagai medianya. Kemudian pada saat membilang, anak melangkah sambil melompat dan mengucapkan bilangannya.

Setelah dilaksanakan penelitian mulai dari siklus I, II dan III dapat disimpulkan bahwa pembelajaran melalui permainan ular tangga yang dimodifikasi berhasil meningkatkan kemampuan konsep bilangan dan lambang pada anak usia dini di kelompok B.

Peningkatan kemampuan konsep bilangan anak semakin meningkat dalam kemampuan memasangkan lambang bilangan dengan bilangan benda-benda setelah melaksanakan kegiatan bermain ular tangga yang di modifikasi. Pada siklus I saat anak memasangkan lambang bilangan 1-5 dengan benda-benda (gambar jagung, gambar strawberry dan gambar kue) presentasenya sebesar 35,89\%. Pada siklus II mengalami peningkatan lagi dalam kemampuan memasangkan lambang bilangan 1-5 dengan benda-benda yakni sebesar 67,35\% dan pada siklus III meningkat kembali sebesar 75,15\%. Dilihat dari setiap siklusnya, kemampuan anak dalam memasangkan lambang bilangan dengan benda-benda semakin meningkat. Hal ini berarti anak di kelas mengalami peningkatan kemampuan konsep bilangan dan lambang dalam hal memasangkan lambang dengan bendabenda.

Berdasarkan gambar grafik di atas dapat terlihat peningkatan kemampuan konsep bilangan anak semakin meningkat dalam kemampuan membilang urutan benda-benda 1-10 setelah melaksanakan kegiatan bermain ular tangga yang di modifikasi. Pada siklus I saat anak membilang urutan benda-benda 1-20 presentasenya sebesar $41,02 \%$. Pada siklus II mengalami peningkatan lagi dalam kemampuan membilang urutan benda- benda 1-20 1-5 yakni sebesar 58,16\% dan pada siklus III meningkat kembali sebesar $75,15 \%$. Dilihat dari setiap siklusnya, kemampuan anak dalam membilang urutan benda-benda 1-20 semakin meningkat. 
Hal ini berarti anak di kelas mengalami peningkatan kemampuan konsep bilangan dan lambang dalam hal membilang uritan benda-benda 1-20.

Peningkatan kemampuan konsep bilangan anak semakin meningkat dalam kemampuan meniru bentuk lambang bilangan 1-5 setelah melaksanakan kegiatan bermain ular tangga yang di modifikasi. Pada siklus I saat anak meniru bentuk lambang bilangan 1-10 presentasenya sebesar 25,63\%. Pada siklus II mengalami peningkatan lagi dalam meniru benuk lambang bilangan 1-10 yakni sebesar 43,82\% dan pada siklus III meningkat kembali sebesar 64,07\%. Dilihat dari setiap siklusnya, kemampuan anak dalam meniru bentuk lambang bilangan 110 semakin meningkat. Hal ini berarti anak di kelas mengalami peningkatan kemampuan konsep bilangan dan lambang dalam hal meniru bentuk lambang bilangan.

Dari hasil penelitian yang telah dilaksanakan, kegiatan pembelajaran dengan menggunakan metode permainan ular tangga modifikasi berhasil meningkatkan kemampuan konsep bilangan dan lambang anak di kelompok B. Hal ini dapat dilihat dari hasil peningkatan setiap indikator dari siklus I, II dan III. Keberhasilan dari penelitian ini ditunjang oleh beberapa hal yakni kemampuan peneliti dalam merancang kegiatan pembelajaran yang beragam, menciptakan suasana yang nyaman dan menyenangkan serta penggunaan media yang tidak bisa lepas dari permainan ini sebagai pendukung untuk melakukan permainan ular tangga modifikasi.

\section{KESIMPULAN}

Proses pembelajaran dengan modifikasi permainan ular tangga dalam meningkatkan kemampuan konsep bilangan dan lambang anak usia dini dilaksanakan melalui langkah-langkah pembelajaran pada setiap siklusnya. Pada siklus I kegiatan pembelajaran modfikasi permainan ular tangga dilakukan di lantai, setiap anak memiliki bidaknya masing- masing . pada saat bermain, anakanak mengantri untuk melakukan giliran bermain ular tangga. Meskipun pada saat pertama kali pembelaran menggunakan ular tangga modifikasi anak-anak masih belum terlihat antusias, anak-anak terlihat bosan dan kebingungan. Akan tetapi, setelah guru melakukan perbaikan dari setiap tindakannya, proses pembelajaran menjadi kondusif, anak-anak terlihat antusias, mampu mengikuti instruksi guru, mengikuti permainan ular tangga dan memahami aturan permainan ular tangga. Pada siklus II kegiatan pembelajaran modifikasi permainan ular tangga dilakukan dengan cara di tembok, bidak pun digantungkan pada papan ular tangga yang terbuat dari strerofom. Namun pada tindakan 2 guru menggantikan cara permainan ular tangga di lantai karena di tembok anak terlihat kesusahan. Namun mulai antusias sehingga kegiatan pembelajaran berlangsung dengan baik dan di siklus III proses pembelajaran sudah terlihat lebih kondusif dan anak- anak terlihat lebih antusias dan semangat setiap kali akan bermain ular tangga modifikasi karena indera anak dapat dilibatkan langsung.

Kemampuan konsep dan lambang bilangan anak usia dini melalui modifkasi permainan ular tangga meningkat dengan baik dan signifikan. Terlihat dari setiap siklus mengalami peningkatan yang baik. Siklus I

a. Indikator 1 yaitu memasangkan lambang bilangan dengan benda- benda (gambar jagung, gambar strawberry, gambar kue) 1-10 di siklus I sebesar 35,89\% dari 16 
orang anak yaitu sebanyak 5 anak, di siklus II dalam memasangkan lambang bilangan dengan benda- benda (gambar tomat, ikan plastisin, perahu kertas) meningkat sebesar 67,35\% yaitu sebanyak 10 anak dan pada siklus III dalam memasangkan lambang bilangan dengan benda-benda (anak, potongan ubi dan singkong, bendera) meningkat sebesar $75,15 \%$ yaitu sebanyak 12 anak.

b. Indikator 2 yaitu membilang urutan benda-benda 1-20 di siklus I sebesar 41,02\% yaitu sebanyak 6 anak, sebesar $58,16 \%$ yaitu $64,07 \%$ yaitu meningkat lagi sebesar $75,15 \%$ yaitu 12 anak.

c. Indikator 3 yaitu meniru bentuk lambang bilangan 1-10 di udara pada siklus I sebesar 25,63 yaitu sebanyak 4 anak, di siklus II dalam meniru bentuk lambang bilangan di pasir meningkat sebesar $45,82 \%$ yaitu sebanyak 7 anak dan siklus III dalam meniru bentuk lambang bilangan di plastisin meningkat kembali sebesar sebanyak 10 anak.

\section{DAFTRA PUSTAKA}

Himpunan Peraturan Perundang-Undangan. (2013). Undang-undang sisdiknas. Bandung: Fokus Media.

Syaripudin, T. (2003). Landasan kependidikan taman kanak-kanak. Bandung: UPI.

Depdiknas. (2007). Pedoman pembelajaran bidang pengembangan kognitif di taman kanak-kanak. Jakarta: Depdiknas.

Depdiknas. (2007). Pedoma pembelajaranpermainan berhitung permulaan di taman kanak-kanak. Jakarta: Depdiknas.

Laelasari, N, I. (2012). Penggunaan permainan ular tangga untuk meningkatkaN kemampuan membilang pada anak TK. Bandung: tidak diterbitkan.

Sriningsih, N. (2009). Pembelajaran matematika terpadu untuk anak usia dini. Bandung: Pustaka Sebelas

Wardani, D. (2009). Bermain sambil belajar menggali keunggulan rahasia terbesar dari suatu permainan. Bandung: Edukasia.

Abidin, Y. (2011). Penelitian pendidikan dalam gamintan pendidikan dasar danpaud. Bandung: Rizqi Press.

Sanjaya, W. (2013). Strategi pembelajaran berorientasi standar proses pendidikan. Jakarta: Kencana Prenadamedia Group.

Solehuddin. (2002). Konsep dasar pendidikan prasekolah. Bandung: FIP UPI.

Cakrawala Dini. (2013). Jurnal pendidikan anak usia dini. Bandung: Pusat Kajian PAUD Kampus Cibiru.

Mariyana, dkk. (2010). Pengelolaan lingkungan belajar. Jakarta: Kencana Prenada Media Group.

Mulyati, T. (2010). Dimensi-dimensi pembelajaran pada pendidikan anak usia dini. Bandung: Rizqi Press. 